\title{
Community engagement in Ebola outbreaks in sub- Saharan Africa and implications for COVID-19 control: A systematic review
}

Shadrack Osei Frimpong ( $\sim$ sof20@cam.ac.uk)

University of Cambridge

Elijah Paintsil

Yale University

\section{Systematic Review}

Keywords: Ebola Virus, Outbreak, Africa, Community Engagement, Rural Health

Posted Date: January 6th, 2022

DOI: https://doi.org/10.21203/rs.3.rs-1235245/v1

License: (c) (1) This work is licensed under a Creative Commons Attribution 4.0 International License.

Read Full License

Version of Record: A version of this preprint was published at International Journal of Infectious Diseases on December 1st, 2022. See the published version at https://doi.org/10.1016/j.ijid.2022.11.032. 


\section{Abstract \\ Objectives}

There is a paucity of systematic data on the specific roles community engagement played in preventing and managing the Ebola Virus Disease (EVD) outbreak in Sub-Saharan Africa (SSA). We assessed community engagement's role, benefits, and mechanisms to understand its effect on EVD case detection, survival, and mortality in SSA. Implications for COVID-19 prevention and control were also highlighted.

\section{Methods}

We systematically searched for articles between 2010 and 2020 in databases such as MEDLINE and EMBASE. Study types included were randomised trials, quasi-experimental studies, observational studies, case series, and reports.

\section{Results}

A total of 903 records were identified for screening. 216 articles met the review criteria, 103 were initially selected, and 44 were included in the final review. Our findings show that effective community involvement during the EVD outbreak depended on the survival rates, testimonials of survivors, risk perception, and community leaders' inclusion. Community-based interventions improved knowledge and attitudes, case findings, isolation efforts and treatment.

\section{Conclusion}

Although the studies included in this review were of highly variable quality, community engagement lessons learned from Ebola outbreaks can be applied to COVID-19 pandemic control in SSA.

\section{Introduction}

Ebola virus is the etiological agent of the Ebola Virus Disease (EVD), a hemorrhagic fever that occurs in epidemics in the west and equatorial Africa as defined by (Malvy et al., 2019). The virus was named after the river 'Ebola' in the Democratic Republic of Congo, where the first EVD outbreak occurred in 1976. According to (Khallafalah et al., 2017), it is an enveloped, negative-sense, single-stranded RNA virus belonging to the genus Ebolavirus and the Filoviridae family. There are five species of Ebola viruses: Zaire, Bundibugyo, Sudan, Côte d'Ivoire (Taï Forest), and Reston as shown in (Kourtis et al, 2015). It is transmitted in humans through close contact with blood or bodily fluids from an infected individual or animal. The main clinical manifestations of EVD are fever, myalgia, abnormal inflammatory responses, dehydration, electrolyte imbalance, haemorrhage, and sometimes death (Laupland and Valiquette, 2014) 
Since the first outbreak in 1976, several epidemics have occurred in sub-Saharan Africa, which have claimed thousands of lives. A recent outbreak in 2014-2016 in West Africa was the most widespread to date, killing over 11,000 people with a case fatality rate of over $40 \%$, as stated in (CDC 2020). There is an ongoing outbreak in the Democratic Republic of Congo, with more than 3,470 and 2,287 cases and deaths, respectively, as of August 18, 2020, according to (MSF 2020).

A community refers to individuals bound by a geographical boundary and sharing social, traditional, or economic interests (Cyril et al., 2015). Community engagement is how organisations and individuals work collaboratively with communities to achieve a collective vision (WHO, 2020). A successful community engagement seeks the active involvement of community members in program design, leadership, implementation, and monitoring and evaluations (WHO, 2020). There are two main community engagement strategies: community coalition and community-based participatory research (CBPR). Community coalition aims to improve health outcomes either indirectly through enhanced participation or directly through policy changes with a specific health target (Wallerstein et al., 2011). CBPR is a collaborative research approach that involves all partners- academics, practitioners, and community members - with an overall goal of combining knowledge and action for social change to improve community health and reduce health disparities (Wallerstein et al., 2011). These community engagement strategies avoid the prevalent "top-down" dynamic between community interventionists and community members. These strategies decentralise power, decision-making and create a shared responsibility to design culturally appropriate and sustainable programs.

Community engagement is a crucial tool in improving population health and empowers communities to be responsible for their health, as discussed in (Israel et al., 1998). Historically, community-based approaches have been effective in addressing complex health challenges. For instance, the HIV Equity Initiative (HEI) successfully worked with community members in Haiti's lower Central Plateau to improve HIV treatment uptake (Farmer et al., 2001). This was achieved by assigning patients to specific community health workers who monitored the patients' medication adherence, met with patients monthly and provided patients with social support, such as paying school fees for children whose parents were HIV-positive. With the engagement of the local government, HEI was able to change behaviours associated with the spread of new infections.

It is well established that interventions to address public health challenges cannot be "one-size-fits-all" and must be tailored for their specific regions and contexts (Israel et al., 1998; Farmer et al., 2001). While the role of community engagement in disease conditions such as HIV/AIDS, tuberculosis, maternal and infant care has received much attention, there is a paucity of systematic data on the specific roles it played in the prevention and management of the EVD outbreak in SSA. Consequently, there is a knowledge gap in how community engagement can address other SSA outbreaks, such as future EVD outbreaks and the ongoing COVID-19 pandemic.

This review aimed to examine the effects of community engagement on EVD case detection, survival, deaths in sub-Saharan Africa and assess critical factors and attributes of successful community 
engagement. The findings will inform best community engagement practices to control and prevent similar outbreaks.

\section{Materials And Methods}

\section{Search Strategy and Eligibility Criteria}

The study was a systematic review. We searched key electronic databases such as MEDLINE and EMBASE and identified relevant articles on PubMed, Google Scholar, Google, and ResearchGate. The eligibility criteria entailed a broad array of studies, including randomised trials, quasi-experimental studies, observational studies, case series and reports, with participants such as communities and individuals in African countries afflicted with EVD, including healthcare providers, governmental and nongovernmental organisations. The articles must also be published in English. The search terms included community engagement during the Ebola outbreak as one or more of the following: community-based prevention and care, community surveillance systems, community health workers, involving local community leaders, community members and local medical staff, social mobilisation, or community implementation. Date restriction from 2010 to 2020 was imposed on the search, but the priority was given to the relevance of the materials in terms of their substantial contribution to the discourse on EVD.

\section{Article Selection and Information Extraction}

We evaluated all titles and abstracts to determine their relevance and eligibility. Literature that did not meet the eligibility criteria were excluded. There was not enough information to decide based on the abstract and title; we obtained the full text and reviewed it accordingly to determine. Copies of the full text of potentially relevant references were obtained and reviewed to ensure they met the eligibility criteria. Where necessary, opinions were resolved by discussion among the authors who have varied expertise on the topic.

Our search results generated studies that were mainly observational and quasi-experimental.; We identified 896 titles from the search conducted in all databases and seven from the reference list of the screened studies culminating in a total of 903 records; 680 studies were excluded mainly because they did not use any of the interventions stated in our eligibility criteria. After screening titles and abstracts, 216 full texts were reviewed and screened further (Figure 1). Of the 216 full texts studied, 103 were initially selected, while 113 articles did not meet inclusion criteria based on the full-text screening. Fortyfour articles were finally included because they met all the eligibility requirements, whereas 59 articles were not included based on their methods, key findings and contributions.

The authors performed the information extraction process, and any discrepancies that emerged were discussed among themselves. For each article, the following information was documented: author(s), year of publication, country, study design, type of intervention, community engagement factors (if any), and primary outcome(s). 


\section{Quality Screening}

We assessed the quality of articles included using the Joanna Briggs Institute (JBI) Appraisal Checklist and the NIH Quality Assessment Tools for Observational and Cross-Sectional Studies (Supplementary Tables). In each assessment, we screened for sources of selection bias such as convenience sample or location, potential blinding of outcomes in the included studies, and further evaluated these studies to see if authors selectively reported positive or significant results and left out negative results. We also assessed the blinding of participants and personnel (patients and treatment providers) and checked to see if some participants knew the intervention or not. Finally, we evaluated studies to see if there was any proportion of subjects whose outcomes were not recorded at the end of the study because of follow-up loss.

\section{Results}

Of the 44 articles that were finally included, 19 were cross-sectional and observational studies, 13 were qualitative studies, 3 were pre-post studies with no control groups, 6 were quasi-experimental studies, 2 were opinion pieces that merited inclusion based on our qualitative assessment, and 1 was a metaanalysis as illustrated with the PRISMA table in Figure 1.

\section{Figure 1 here}

Table 1 summarises the findings of community-based interventions and their significant outcomes. There were 33 different studies from 6 different countries, most of them conducted in Liberia and Sierra Leone. Of the 33, there were 15 different types of community-based interventions, many of them focused on community-based education and mobilisation (Reaves et al., 2012; Sepers et al., 2019; Blackley et al., 2015; Hagan et al., 2015; Williams et al., 2015; Li et al., 2016; Fallah et al., 2016; Jiang et al., 2016). Others included community-based surveillance systems, as discussed in (Miglietta et al. 2019; Tiffany et al., 2016; Ratnayake et al., 2016; Sacks et al., 2015). Mobile Health (MHealth) and technology-based tools (Jia and Mohammed, 2015; Nic et al., 2018; Out et al. 2016, McMahon et al., 2016). There were also the integration of community members into formal healthcare systems (Siekmans et al., 2017; Miller et al., 2018; Pronyk et al. 2016), survivor reintegration programs (Reaves et al., 2014; Carter et al., 2017), community care centres (CCCs) (Nyenswah et al., 2015; Pellecchia et al. 2015) and community quarantine initiatives (Okware et al., 2015; Capps et al., 2017). Other interventions included joint community mobilisation and palliative care (Sharma et al., 2014),community-led total sanitation (Abramowitz et al., 2017), community-based Ebola Treatment Units (ETUs) (Roess et al., 2017), a nonvideo health communication campaign (Turay, 2017), a video-centred health communication intervention (Fallah et al., 2017), and interpersonal communication approach (Caleo et al., 2018) and then a joint field blood draw and point of care diagnostics (Gray et al., 2018).

\section{Table 1 here}


A summary of the frequency of these interventions as reported in different studies and the countries where the interventions were implemented are illustrated in Table 2.

Table 3 summarises the main factors that impacted the level of community engagement during Ebola response efforts. Some of the key factors that influenced community involvement were the survival rates of those who were infected (Nyakarahuka et al., 2017; Masumbuko et al., 2019) testimonials of survivors during their re-integration(Nyakarahuka et al., 2017; Masumbuko et al., 2019), risk perception of EVD ( Jiang et al., 2016; Vinck et al., 2019; Along et al., 2019; Abramowitz et al., 2015), and the role of local leaders in garnering community trust (Masumbuko et al., 2019; de Vries et al., 2016; Lee-Kwan et al., 2017). Additionally, proximity to a healthcare facility (Maumbuko et al., 2019), clarity in communication (Nyakarahuka et al., 2017; Stone et al., 2016), engagement of community members in safe burials(Roess et al., 2017; Lee-Kwan et al., 2017; Kirsch et al., 2017) top-down or bottom-up government approaches (Capps et al., 2017), donor-community collaborations ( Reaves et al., 2014; Pellecchia et al., 2015; Kasereka et al. 2019; Carrión Martin et al., 2016), level of satisfaction with EVD response (Thiam et al., 2015), acceptance or denial of biomedical discourse (Thiam et al., 2015) and community resilience ( Hagan et al., 2015; de Vries et al., 2016) all impacted the level of community engagement.

\section{Tables 2 \&3 here}

\section{Discussion}

We found that community-based interventions such as community education and mobilisation, survivor reintegration programs, and community-based surveillance systems helped to improve case finding, isolation and treatment as shown in (Reaves et al., 2014; Williams et al., 2015; Li et al., 2016; Fallah et al. 2016). Moreover, community-based interventions improved knowledge, attitudes, and behaviours towards EVD response efforts and helped flatten the EVD epidemic curve (Sepers et al., 2019; Hagan et al., 2015; Jiang et al., 2016). Factors such as survival rates of those infected, testimonials of survivors during their re-integration, risk perception of EVD, and the role of local leaders in garnering community trust helped ensure effective community engagement (Reaves et al., 2014; Carter et al., 2017). In addition, we found that proximity to a healthcare facility, clarity in communication, engagement of community members in safe burials, bottom-up government approaches, donor-community collaborations, level of satisfaction with the EVD response (Kasereka et al., 2019), acceptance or denial of biomedical discourse (Kasereka et al., 2019), and community resilience were also associated with whether any of the community-based interventions we reviewed were successful or not (Reaves et al., 2014; Okware et al., 2015; Capps et al., 2017; Masumbuko et al., 2019; Stone et al., 2016).

Our findings suggest that community-based interventions focused on community education and mobilisation are effective in improving early case detection, isolation, treatment, and significant positive changes in EVD knowledge and attitudes among community members (Reaves et al., 2014; Sepers et al., 2019, Blackley et al., 2015; Hagan et al., 2015; Williams et al., 2015, Li et al., 2016; Fallah et al., 2016; Jiang et al., 2016). 
Survivor reintegration programs, jointly championed by community members and private partners such as Firestone Liberia, Inc., also markedly contributed to successful control of EVD outbreak (Reaves et al., 2015; Carter et al., 2017). The return of survivors and the testimonials of excellent Ebola Treatment Unit care that they received were critical in engendering community trust and social mobilisation. In particular, the role of survivor integration efforts in health promotion was even more prominent in countries like Sierra Leone, where survivor testimonials were deemed more effective communication tools than those of the mass media seen by community members as top-down and imposed.

Community-based surveillance systems also helped improve alert reporting, case finding, and eventual isolation (Tiffany et al., 2016; Ratnayake et al., 2015; Sacks et al., 2015; Kasereka et al., 2019). Although, in some instances, these generated false alerts (Ratnayake et al., 2015; Sacks et al., 2015). For example, in Sierra Leone, community-based surveillance helped detect EVD cases even though it produced a side effect of false alerts (Sacks et al., 2015).

These interventions can be scaled-up considerably at the community level to target vulnerable populations such as those geographically remote communities and have unique cultural dynamics. However, such scale-up efforts may come with implementation and long-term sustainability challenges that should be accounted for in advance (Reaves et al., 2014; Sepers et al.,2019; Vinck et al., 2019; Dickmann et al., 2018).

We observed that the reported positive outcomes were much higher for almost all the interventions when there were more components. For instance, joint community mobilisation and palliative care helped to improve case detection and treatment, and a patient's odds of survival significantly than if community mobilisation alone was conducted (Sharma et al., 2014). Also, community education and mobilisation interventions that combined reporting, case finding and isolation, education and training in hygienic burial practices produced better outcomes than when these interventions were deployed alone (Blackley et al., 2015; Li et al., 2016). Similarly, the use of cell phones in conducting surveillance performed better than traditional community-based surveillance systems. It may be helpful as a supplementary tool to address the challenges of false alerts generated in conventional surveillance systems. Despite software and internet connectivity challenges, devices such as cell phones can help to improve data access and data collection and accelerate case death reporting (Jia and Mohammed, 2015).

As a community-based intervention, the joint field blood draw and point of care diagnostics initiative and its success shed light on the potential of combining home-based care and point of contact diagnostics. ${ }^{42}$ Future implementation science studies should explore the efficacy of home-based care and its role in accelerating EVD diagnosis and isolation. (Fallah et al., 2014) found that contrary to initial concerns, no healthcare worker or household member of the patient treated at home got infected with the disease. In times of epidemics, this will be important in communities with unique cultural dynamics where infected community members may resist admission to treatment facilities. Such resistance to medical care will increase mortality rates for the infected and put the lives of the non-infected in jeopardy by increasing their risk of community transmission. 
Partnerships between private companies and their operating communities, such as those between Firestone Liberia Inc. and community members in Firestone District, Liberia, could serve as a model for how other private companies can contribute to response efforts during epidemics. When the EVD epidemic broke out among some of their staff members and their communities, Firestone Liberia Inc. could successfully engage community members and quickly work with them to reduce EVD cases (Reaves et al., 2014). This shows that multilateral organisations like WHO are not the only nongovernmental entities to help stop epidemics. Private for-profit companies also have a role to play. This is especially important given the limited funding available for control efforts in times of outbreaks (Sanogo, 2019).

Community resilience: the sense of self-responsibility and agency that community members wield in addressing their challenges also played a crucial role in slowing the epidemic. One of the biggest challenges in global health today is inadequate health financing. This problem is particularly heightened during emergencies such as epidemics where the international community has at its disposal limited funding to implement control efforts. Yet, in the face of financial difficulties, we can learn from the critical roles that community resilience played in flattening the EVD epidemic curve. For instance, during the EVD epidemic, many resilient communities could adopt measures that enable them to support each other long before their health workers arrived (Hanefield et al.,2018). This was particularly important in rural and remote communities where geographic barriers delayed access to treatment. In some communities, resilience achieved through solid social cohesion, respect for community culture, social capital and robust community leadership, as opposed to foreign aid that is top-down in nature, proved to be the best option to stop an outbreak (de Vries et al., 2016; Stone et al., 2016). Community resilience has historically proved important in preparing, implementing, and declining outbreaks such as the 1918 Influenza and the ongoing HIV/AIDS pandemic. Investing in initiatives that strengthen community resilience in rural and remote communities in sub-Saharan Africa before and during disease outbreaks may help save lives and be cost-effective.

Barely before the EVD epidemic could become a far thought, the severe acute respiratory syndrome coronavirus 2 (SARS-CoV-2) causing coronavirus disease-2019 (COVID-19) emerged. With millions of lives affected and hundreds of thousands of deaths recorded, proper measures must be put in place to stem the pandemic, especially in parts of the world like sub-Saharan Africa, where health systems are incredibly fragile. While the WHO currently reports that Africa remains the least affected continent with COVID-19, with $1.5 \%$ of the world's cases, and $0.1 \%$ of globally reported deaths, there is no cause for celebration and complacency (Sanogo, 2019). This is because community transmissions are ongoing amidst limited testing capacity in most African countries, particularly in rural and remote communities (Paintsil, 2020). The EVD outbreaks provide a unique opportunity to leverage COVID-19 prevention and control lessons. Existing evidence argues that during the EVD outbreaks, international efforts in Liberia arrived after the epidemic had subsided. Much of the flattening of the epidemic curve was due to significant behavioural changes at the community level (Carrión Martín et al., 2016). In the same vein, community-based interventions should be prioritised as a part of COVID-19 control efforts, with 
community leaders leading the charge in engaging their community members and enacting bye-laws, where necessary. COVID-19 survivors should also be made a key component of such interventions. Their testimonies may help to engender trust between community members and healthcare workers and encourage health-seeking behaviours. This would minimise chances of community resistant events that may potentially arise in the absence of community engagement (Pronyk et al., 2016). Additionally, individual and communal quarantines during the EVD outbreaks could shed light on how to ensure that COVID-19 quarantines and lockdowns are similarly effective. Top-down approaches such as stateenforced, military-style quarantines elicited protests, violence and deaths while community-led voluntary quarantine initiatives were successful (Capps et al., 2017).

\section{Conclusions}

Governments and international stakeholders should prioritise the goal of engaging community leaders and members before initiating any intervention. During quarantine, communities must have access to necessities such as food, water and medical services, as shown in (Okware et al., 2015; Lee-Kwan et al., 2017). Finally, given the paucity of funding for COVID-19, there is a great need to focus on community resilience in rural and remote places and engage the efforts of private partners as Firestone Liberia Inc., and ALIMA did during the EVD outbreaks.

Our review sheds light on the impact of community-based interventions during the EVD epidemic and factors associated with successful community engagement. Nonetheless, it is not without limitations. The overall quality of the studies included in this review was highly variable. Also, many studies had poorly described methods, making it challenging to evaluate biases such as social desirability bias and performance bias.

Several community-based interventions were instrumental in controlling EVD outbreaks, and their implementation successes or failures were hinged on myriads of factors that hampered community engagement efforts. Lessons learned on community engagement during EVD outbreaks can be leveraged in fighting other attacks such as COVID-19. It is imperative to engage community members to execute community-based initiatives for pandemic preparedness and control.

\section{Declarations}

Conflict of Interest: The authors declare no conflicts of interest.

Funding Source: This research did not receive any specific grant from funding agencies in the public, commercial, or not-for-profit sectors.

Ethical Approval Statement: This study was a systematic review and was exempt from ethics approval. The authors gathered and synthesised data from previous studies in which the respective investigators have already obtained informed consent. 
Acknowledgement: The authors would like to thank Kris Hilton, Sharon Attipoe-Dorcoo, Priya D. Bhirgoo, Frida Aloo, and Angela Kumirai for their helpful edits and comments.

\section{References}

1. Abramowitz S, McKune S L, Fallah M, Monger J, Tehoungue K, Omidian PA. The Opposite of Denial: Social Learning at the Onset of the Ebola Emergency in Liberia. J Health Commun 2017;22:59-65.

2. Abramowitz SA, McLean KE, McKune SL, Bardosh KL, Fallah M, Monger J, et al. Community-centered responses to Ebola in urban Liberia: the view below. PLoS Negl Trop Dis 2015;9:e0003706.

3. Alonge O, Sonkarlay S, Gwaikolo W, Fahim C, Cooper JL, Peters DH. Understanding the role of community resilience in addressing the Ebola virus disease epidemic in Liberia: a qualitative study (community resilience in Liberia). Glob Health Action 2019;12:e1662682.

4. Blackley DJ, Lindblade KA, Kateh F, Broyles LN, Westercamp M, Neatherlin JC, et al. Rapid intervention to reduce Ebola transmission in a remote village - Gbarpolu County, Liberia, 2014. MMWR Morb Mortal Wkly Rep 2015: 64:175-178.

5. Caleo G, Duncombe J, Jephcott F, Lokuge K, Mills C, Looijen E, et al. The factors are affecting household transmission dynamics and community compliance with Ebola control measures: a mixed-methods study in a rural village in Sierra Leone. BMC Public Health 2018;18:248.

6. Capps JM, Njiru H, deVries P. Community-Led Total Sanitation, Open Defecation Free Status, and Ebola Virus Disease in Lofa County, Liberia. J Health Commun 2017;22:72-80.

7. Carrión Martín Al, Derrough T, Honomou P, Kolie N, Diallo B, Kone M, et al. Social and cultural factors behind community resistance during an Ebola outbreak in a village of the Guinean Forest region, February 2015: a field experience. Int Health 2016;8:227-229.

8. Carter SE, O'Reilly M, Frith-Powell J, Umar Kargbo A, Byrne D, Niederberger, E. Treatment Seeking and Ebola Community Care Centers in Sierra Leone: A Qualitative Study. J Health Commun 2017;22:6671.

9. Community Engagement (PowerPoint presentation) | Module B5 | World Health Organisation (WHO). https://www.Who.Int/Risk-Communication/Training/Module-B5.Pdf, 2020 (accessed 15 Dec 2020).

10. Cyril S, Smith BJ, Possamai-Inesedy A, Renzaho, AMN. Exploring the role of community engagement in improving the health of disadvantaged populations: a systematic review. Glob Health Action 2015;8:29842.

11. De2016;16:161.

12. Dickmann, P, Kitua A, Apfel F, Lightfoot, N. Kampala manifesto: Building community-based One Health approaches to disease surveillance and response-The Ebola Legacy-Lessons from a peer-led capacity-building initiative. PLoS Negl Trop Dis 2018;12:e0006292.

13. DRC Ebola outbreak crisis update I MSF. Médecins Sans Frontières (MSF) International. https://www.msf.org/drc-ebola-outbreak-crisis-update, (accessed 30 Jun 2020). 
14. Ebola Outbreak in West Africa (2014-2016) | History | Ebola (Ebola Virus Disease) | CDC. https://www.cdc.gov/vhf/ebola/history/2014-2016-outbreak/index.html, (accessed 30 Jun 2020).

15. Fallah MP, Skrip LA, Raftery P, Kullie M, Borbor W, Laney AS, et al. Bolstering Community Cooperation in Ebola Resurgence Protocols: Combining Field Blood Draw and Point-of-Care Diagnosis. PLoS Med 2017;14:e1002227.

16. Fallah, M, Dahn, B, Nyenswah, TG, Massaquoi M, Skrip LA, Yamin D, et al. Interrupting Ebola Transmission in Liberia Through Community-Based Initiatives. Ann Intern Med 2016;164:367-369.

17. Farmer P, Léandre F, Mukherjee JS, Claude MS, Nevil P, Smith-Fawzi MC, et al. Community-based approaches to HIV treatment in resource-poor settings. Lancet 2001;358:404-409.

18. Gray N, Stringer B, Bark G, Perache AH, Jephcott F, Kremer R, et al. 'When Ebola enters a home, a family, a community': A qualitative study of population perspectives on Ebola control measures in rural and urban areas of Sierra Leone. PLoS Negl Trop Dis 2018;12(6):e0006461.

19. Hagan JE, Smith W, Pillai SK, Yeoman K, Gupta S, Neatherlin J,et al. Implementation of Ebola casefinding using a village chieftaincy taskforce in a remote outbreak - Liberia, 2014. MMWR Morb Mortal Wkly Rep, 2015:64;183-185.

20. Hanefeld J, Mayhew S, Legido-Quigley H, Martineau F, Karanikolos M, Blanchet K, et al. Towards an understanding of resilience: responding to health systems shocks. Health policy and planning 2018;33(3):355-367.

21. Israel BA, Schulz AJ, Parker EA, Becker AB. Review of community-based research: assessing partnership approaches to improve public health. Annu Rev Public Health 1998;19:173-202.

22. Jia K, Mohamed K. Evaluating the use of cell phone messaging for community Ebola syndromic surveillance in high risked settings in Southern Sierra. Afr Health Sci 2015;15(3): 797-802.

23. Jiang H, Shi GQ, Tu WX, Zheng CJ, Lai XH, Li XX, et al. Rapid assessment of knowledge, attitudes, practices, and risk perception related to the prevention and control of Ebola virus disease in three communities of Sierra Leone. Infect Dis Poverty 2016; 5:53.

24. Kasereka MC, Sawatzky J, Hawkes, MT. Ebola epidemic in war-torn Democratic Republic of Congo, 2018: Acceptability and patient satisfaction of the recombinant Vesicular Stomatitis Virus - Zaire Ebolavirus Vaccine. Vaccine. 2019; 37: 2174-2178.

25. Khalafallah MT, Aboshady OA, Moawed SA, Ramadan MS. Ebola virus disease: Essential clinical knowledge. Avicenna J Med 2017;7:96-102.

26. Kirsch TD, Moseson H, Massaquoi M, Nyeswah TG, Goodermote R, Rodriguez-Barraquer I, et al. Impact of interventions and the incidence of ebola virus disease in Liberia-implications for future epidemics. Health Policy Plan 2017;32: 205-214.

27. Kourtis AP, Appelgren K, Chevalier MS, McElroy A. Ebola Virus Disease: Focus on Children. Pediatr Infect Dis J 2015;34:893-897.

28. Laupland KB, Valiquette L. Ebola virus disease. Can J Infect Dis Med Microbiol 2014; 25: 128-129. 
29. Lee-Kwan SH, DeLuca N, Bunnell R, Clayton HB, Turay AS, Mansaray Y. Facilitators and Barriers to Community Acceptance of Safe, Dignified Medical Burials in the Context of an Ebola Epidemic, Sierra Leone, 2014. J Health Commun 2017;22:24-30.

30. Li ZJ, Tu WX, Wang XC, Shi GQ, Yin ZD, Su HJ, et al. A practical community-based response strategy to interrupt Ebola transmission in Sierra Leone, 2014-2015. Infect Dis Poverty 2016;5:74.

31. Malvy D, McElroy AK, de Clerck H, Günther S, Van Griensven J. Ebola virus disease. Lancet 2019;393:936-948.

32. Masumbuko Claude K, Underschultz J, Hawkes MT. Social resistance drives persistent transmission of Ebola virus disease in Eastern Democratic Republic of Congo: A mixed-methods study. PLoS One 2019;14:e0223104.

33. McMahon SA, Ho LS, Scott K, Brown H, Miller L, Ratnayake R, et al. "We and the nurses are now working with one voice": How community leaders and health committee members describe their role in Sierra Leone's Ebola response. BMC Health Serv Res 2017;17:495.

34. Miglietta A, Solimini A, Djeunang Dongho GB, Montesano C, Rezza G, Vullo V, et al. The Ebola virus disease outbreak in Tonkolili district, Sierra Leone: a retrospective analysis of the Viral Haemorrhagic Fever surveillance system, July 2014-June 2015. Epidemiol Infect 2019;147:e103.

35. Miller NP, Milsom P, Johnson G, Bedford J, Kapeu AS, Diallo AO, et al. Community health workers during the Ebola outbreak in Guinea, Liberia, and Sierra Leone. J Glob Health 2018;8:e020601.

36. Nic, Lochlainn LM., Gayton I, Theocharopoulos G, Edwards R, Danis K, Kremer R, et al. Improving mapping for Ebola response through mobilising a local community with self-owned smartphones: Tonkolili District, Sierra Leone, January 2015. PLoS One 2018;13:e0189959.

37. Nyakarahuka L, Skjerve E, Nabadda D, Sitali DC, Mumba C, Mwiine F, et al. Knowledge and attitude towards Ebola and Marburg virus diseases in Uganda using quantitative and participatory epidemiology techniques. PLoS Negl Trop Dis 2017;11:e0005907.

38. Nyenswah T, Blackley DJ, Freeman T, Lindblade KA, Arzoaquoi SK, Mott JA, et al. Community quarantine to interrupt Ebola virus transmission - Mawah Village, Bong County, Liberia, AugustOctober, 2014. MMWR Morb Mortal Wkly Rep 2015;64:179-182.

39. Okware SI, Omaswa F, Talisuna A, Amandua J, Amone J, Onek P, et al. Managing Ebola from rural to urban slum settings: experiences from Uganda. Afr Health Sci 2015;15:312-321.

40. Otu A, Ebenso B, Okuzu O, Osifo-Dawodu E. Using a mHealth tutorial application to change knowledge and attitude of frontline health workers to Ebola virus disease in Nigeria: a before-andafter study. Hum Resour Health 2016;14:5.

41. Paintsil E. COVID-19 threatens health systems in sub-Saharan Africa: the eye of the crocodile. J Clin Invest, 2020;130:2741-2744.

42. Pellecchia U, Crestani R, Decroo T, Van den Bergh R, Al-Kourdi Y. Social Consequences of Ebola Containment Measures in Liberia. PLoS One 2015;10:e0143036.

43. Pronyk P, Rogers B, Lee S, Bhatnagar A, Wolman Y, Monasch R, et al. The Effect of Community-Based Prevention and Care on Ebola Transmission in Sierra Leone. Am J Public Health 2016;106:727-732. 
44. Ratnayake R, Crowe SJ, Jasperse J, Privette G, Stone E, Miller L, et al. Assessment of Community Event-Based Surveillance for Ebola Virus Disease, Sierra Leone, 2015. Emerg Infect Dis 2016;22:1431-1437.

45. Reaves EJ, Mabande LG, Thoroughman DA, Arwady MA, Montgomery JM. Control of Ebola virus disease - firestone district, liberia, 2014. MMWR Morb Mortal Wkly Rep 2014; 63:959-965.

46. Roess AA, Di Peppi R, Kinzoni EA, Molouania, M, Kennedy E, Ibata S, et al. Knowledge Gained and Retained from a Video-Centered, Community-Based Intervention for Ebola Prevention, Congo. J Health Commun 2017;22:913-922.

47. Sacks JA, Zehe E, Redick C, Bah A, Cowger K, Camara M, et al. Introduction of Mobile Health Tools to Support Ebola Surveillance and Contact Tracing in Guinea. Glob Health Sci Pract 2015;3:646-659.

48. Sanogo I. COVID-19 in Africa: no room for complacency. Lancet Infect Dis 2020; 395:1669.

49. Sepers CE, Fawcett SB, Hassaballa I, Reed FG, Schultz J, Munodawafa D, et al. Evaluating implementation of the Ebola response in Margibi County, Liberia. Health Promot Int 2019;34:510518.

50. Sharma A, Heijenberg N, Peter C, Bolongei J, Reeder B, Alpha T, et al. Evidence for a decrease in transmission of Ebola virus-Lofa County, Liberia, June 8-November 1, 2014. MMWR Morbidity and mortality weekly report 2014;63(46):1067.

51. Siekmans K, Sohani S, Boima T, Koffa F, Basil L, Laaziz S. Community-based health care is an essential component of a resilient health system: evidence from Ebola outbreak in Liberia. BMC Public Health 2017;17:84.

52. Stone E, Miller L, Jasperse J, Privette G, Beltran JCD, Jambai A, et al. Community event-based surveillance for Ebola virus disease in Sierra Leone: implementation of a national-level system during a crisis. PLoS Currents 2016;8.

53. Thiam S, Delamou A, Camara S, Carter J, Lama EK, Ndiaye B, et al. Challenges in controlling the Ebola outbreak in two prefectures in Guinea: why did communities continue to resist? Pan Afr Med J 2015, 22 Suppl 1.

54. Tiffany A, Moundekeno FP, Traoré A, Haile M, Sterk E, Guilavogui T, et al. Community-Based Surveillance to Monitor Mortality in a Malaria-Endemic and Ebola-Epidemic Setting in Rural Guinea. Am J Trop Med Hyg 2016;95:1389-1397.

55. Turay SD. Behind enemy lines: A perspective on Ebola from Sierra Leone. How the use of interpersonal communication made a difference in the fight against Ebola (An operational intervention). Cogent Medicine 2017;4:e1292890.

56. Vinck P, Pham PN, Bindu KK, Bedford J, Nilles EJ. Institutional trust and misinformation in the response to the 2018-19 Ebola outbreak in North Kivu, DR Congo: a population-based survey. Lancet Infect Dis 2019;19: 529-536.

57. Wallerstein NB, Yen IH, Syme, SL. Integration of social epidemiology and community-engaged interventions to improve health equity. Am J Public Health 2011;101:822-830. 
58. Williams GS, Naiene J, Gayflor J, Malibiche T, Nayeri F, Zoogley B, et al. Twenty-one days of isolation: A prospective observational cohort study of an Ebola-exposed hot zone community in Liberia. $\mathrm{J}$ Infect 2015;71:150-157.

\section{Tables}

Table 1: Type, frequency, and countries of community-based interventions

\begin{tabular}{|lll|}
\hline Type of Community-Based Intervention & $\begin{array}{l}\text { Number of studies } \\
\text { reporting intervention }\end{array}$ & Country (ies) \\
\hline Community-based education and mobilization & 8 & $\begin{array}{l}\text { Liberia; Sierra } \\
\text { Leone }\end{array}$ \\
\hline Community-based surveillance systems & 4 & $\begin{array}{l}\text { Sierra Leone; } \\
\text { Guinea }\end{array}$ \\
\hline $\begin{array}{l}\text { Mobile Health (MHealth) and Technology-based } \\
\text { tools }\end{array}$ & 4 & $\begin{array}{l}\text { Sierra Leone; } \\
\text { Guinea; Nigeria }\end{array}$ \\
\hline $\begin{array}{l}\text { Integration of community health workers, } \\
\text { volunteers and formal health workers, }\end{array}$ & 3 & Liberia, Sierra \\
\hline Survivor Re-Integration Programs & 2 & Leone, Guinea \\
\hline Community Care Centers (CCCs) & 2 & Guinea, Liberia \\
\hline Community Quarantine & 2 & Sierra Leone \\
\hline Active Surveillance and health education & 1 & Liberia \\
\hline Joint Community Mobilization and Palliative Care & 1 & Sierra Leone \\
\hline Community-led total sanitation & 1 & Uganda \\
\hline Non-video health communication campaign & 1 & Liberia \\
\hline $\begin{array}{l}\text { Video-centered health communication intervention } \\
\text { Interpersonal communication approach }\end{array}$ & 1 & Liberia \\
\hline $\begin{array}{l}\text { Joint field blood draw and point of care } \\
\text { diagnostics }\end{array}$ & 1 & Congo \\
\hline Community-based Ebola Treatment Unit (ETU) & 1 & Sierra Leone \\
\hline
\end{tabular}

Table 2: Outcomes of community-based interventions by intervention type, country, and components 


\begin{tabular}{|c|c|c|c|c|}
\hline Studies & $\begin{array}{l}\text { Type of } \\
\text { Community- } \\
\text { Based } \\
\text { Intervention }\end{array}$ & Country & Intervention Components & Main Outcome \\
\hline $\begin{array}{l}\text { Reaves } \\
\text { (2014) }\end{array}$ & CEM & Liberia & $\begin{array}{l}\text { Radio campaigns; } \\
\text { community meetings; } \\
\text { survivor re-integration; } \\
\text { voluntary quarantine; } \\
\text { incident management; case } \\
\text { finding and isolation. }\end{array}$ & $\begin{array}{l}\text { Improved case } \\
\text { detection, isolation } \\
\text { and treatment, and } \\
\text { eventual reduction in } \\
\text { pandemic spread. }\end{array}$ \\
\hline $\begin{array}{l}\text { Sepers } \\
(2014)\end{array}$ & CEM & Liberia & $\begin{array}{l}\text { Safe burials; Social } \\
\text { Mobilization; Engaging } \\
\text { community leaders; Case } \\
\text { Management. }\end{array}$ & $\begin{array}{l}\text { Led to community } \\
\text { involvement in } \\
\text { positive EVD response } \\
\text { activities such as alert } \\
\text { reporting and safe } \\
\text { burials, and this led to } \\
\text { decrease in EVD } \\
\text { spread. }\end{array}$ \\
\hline $\begin{array}{l}\text { Blackley } \\
(2015)\end{array}$ & CEM & Liberia & $\begin{array}{l}\text { Education; alert reporting } \\
\text { system; case investigation; } \\
\text { contact tracing; training in } \\
\text { hygienic burial; case finding } \\
\text { and isolation. }\end{array}$ & $\begin{array}{l}\text { Multi-pronged } \\
\text { intervention led to } \\
\text { complete cessation of } \\
\text { outbreak. }\end{array}$ \\
\hline $\begin{array}{l}\text { Hagan } \\
(2015)\end{array}$ & CEM & Liberia & $\begin{array}{l}\text { Culturally-sensitive safe } \\
\text { burials; engaging a Village } \\
\text { Chieftaincy Taskforce }\end{array}$ & $\begin{array}{l}\text { Positive changes in } \\
\text { EVD awareness; vital } \\
\text { for geographically } \\
\text { distant communities }\end{array}$ \\
\hline $\begin{array}{l}\text { Williams } \\
\text { (2015) }\end{array}$ & CEM & Liberia & $\begin{array}{l}\text { Community education and } \\
\text { information dissemination; } \\
\text { case finding and isolation; } \\
\text { infection control }\end{array}$ & $\begin{array}{l}\text { Epidemic stopped in } \\
\text { community; no new } \\
\text { cases recorded }\end{array}$ \\
\hline Li (2016) & CEM & $\begin{array}{l}\text { Sierra- } \\
\text { Leone }\end{array}$ & $\begin{array}{l}\text { Community education; alert } \\
\text { reporting; contact tracing; } \\
\text { social mobilization }\end{array}$ & $\begin{array}{l}\text { Improved EVD case } \\
\text { detection, zero } \\
\text { infection of healthcare } \\
\text { workers, no unsafe } \\
\text { burials, and EVD-free } \\
\text { goal was achieved } \\
\text { four months earlier in } \\
\text { participating } \\
\text { communities than the } \\
\text { entire Sierra Leone }\end{array}$ \\
\hline $\begin{array}{l}\text { Fallah } \\
(2016)\end{array}$ & CEM & Liberia & $\begin{array}{l}\text { Contact tracing; case finding } \\
\text { and isolation; community } \\
\text { education. }\end{array}$ & $\begin{array}{l}\text { Community } \\
\text { involvement led to } \\
\text { cooperation with } \\
\text { contact tracing and } \\
\text { accelerated case } \\
\text { isolation. }\end{array}$ \\
\hline $\begin{array}{l}\text { Jiang } \\
(2016)\end{array}$ & CEM & $\begin{array}{l}\text { Sierra- } \\
\text { Leone }\end{array}$ & $\begin{array}{l}\text { Intensified Training on EVD } \\
\text { Response. }\end{array}$ & $\begin{array}{l}\text { Positive changes in } \\
\text { EVD knowledge and }\end{array}$ \\
\hline
\end{tabular}

Page 15/21 
attitudes towards EVD response.

\begin{tabular}{lllll}
$\begin{array}{l}\text { Stehling- } \\
\text { Ariza } \\
(2016)\end{array}$ & $\begin{array}{l}\text { Active } \\
\text { Surveillance } \\
\text { and Health } \\
\text { education }\end{array}$ & $\begin{array}{l}\text { Sierra- } \\
\text { Leone }\end{array}$ & $\begin{array}{l}\text { Active surveillance; health } \\
\text { education; ongoing outreach. }\end{array}$ & $\begin{array}{l}\text { Rapid identification of } \\
\text { suspected EVD cases. }\end{array}$ \\
$\begin{array}{l}\text { Pronyk } \\
(2016\end{array}$ & CCCs & $\begin{array}{l}\text { Sierra- } \\
\text { Leone }\end{array}$ & $\begin{array}{l}\text { Social mobilization; } \\
\text { engagement of community } \\
\text { leaders in site selection and } \\
\text { facilities inauguration; mass } \\
\text { media campaigns }\end{array}$ & $\begin{array}{l}\text { Rapid case isolation } \\
\text { compared in CCCs }\end{array}$ \\
\hline compared to other \\
facilities.
\end{tabular}

\begin{tabular}{|c|c|c|c|}
\hline $\begin{array}{l}\text { Carter } \\
\text { (2017) }\end{array}$ & CCCs & $\begin{array}{l}\text { Sierra- } \\
\text { Leone }\end{array}$ & $\begin{array}{l}\text { Construction of CCCs cl } \\
\text { to communities; employ } \\
\text { CCC workers from } \\
\text { community; engaging } \\
\text { community during CCC }\end{array}$ \\
\hline
\end{tabular}

Transparent ETU walls; community engagement in safe burial process; local hotline; active case finding; contact tracing.

\begin{tabular}{|c|c|c|c|}
\hline $\begin{array}{l}\text { Sharma } \\
\text { (2014) }\end{array}$ & $\begin{array}{l}\text { Community- } \\
\text { based ETUs }\end{array}$ & Liberia & $\begin{array}{l}\text { Transparent ETU walls; } \\
\text { community engagement in } \\
\text { safe burial process; local } \\
\text { hotline; active case finding; } \\
\text { contact tracing. }\end{array}$ \\
\hline
\end{tabular}

Alert reporting, case

Sierra-

confirmation, isolation.

Proximity to CCCs reduced fears and stigma; Inclusion in design of CCCs improved community trust in EVD response and care.

Stone

(2016)

CBS

Leone

Rapid scale-up of multi-pronged intervention led to sharp decline in EVD transmission.

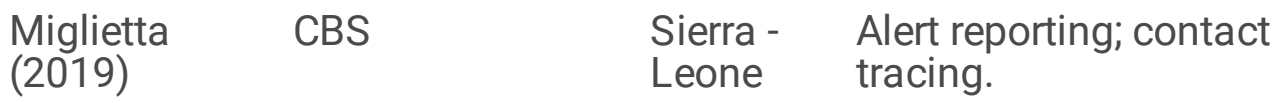

Generated useful, unstructured data at the community level.

Improved EVD alert/case reporting which became exponential over time.

$\begin{array}{lll}\begin{array}{l}\text { Tiffany } \\ (2016)\end{array} \quad \text { CBS } & \text { Guinea } & \begin{array}{l}\text { Reporting and data } \\ \text { collection. }\end{array}\end{array}$

Community surveillance captured information in areas with poor data collection; yet it was hard to determine the cause of deaths.

\begin{tabular}{|c|c|c|c|}
\hline $\begin{array}{l}\text { Ratnayake } \\
(2016)\end{array}$ & CBS & $\begin{array}{l}\text { Sierra- } \\
\text { Leone }\end{array}$ & $\begin{array}{l}\text { Alert reporting; training of } \\
\text { health officers and } \\
\text { surveillance supervisors. }\end{array}$ \\
\hline
\end{tabular}

Community surveillance detected EVD cases, but generated lots of false alerts.

$\begin{array}{llll}\text { Sacks } & \text { Mhealth \& } & \text { Guinea } & \begin{array}{l}\text { Mhealth app on phones for } \\ \text { tracking. }\end{array} \\ & \begin{array}{l}\text { Technology- } \\ \text { based } \\ \text { surveillance } \\ \text { tools }\end{array} & & \end{array}$

Potential impact of improving access to data and case detection; yet has limitations of software malfunctioning; and technical literacy, and data privacy concerns. 


\begin{tabular}{|c|c|c|c|c|}
\hline Jia (2015) & $\begin{array}{l}\text { Mhealth \& } \\
\text { Technology- } \\
\text { based } \\
\text { surveillance } \\
\text { tools }\end{array}$ & $\begin{array}{l}\text { Sierra- } \\
\text { Leone }\end{array}$ & Cell phone messaging. & $\begin{array}{l}\text { Cell phones performed } \\
\text { better (in terms of } \\
\text { reporting) than } \\
\text { traditional surveillance } \\
\text { systems. }\end{array}$ \\
\hline $\begin{array}{l}\text { Lochlainn } \\
\text { (2018) }\end{array}$ & $\begin{array}{l}\text { Mhealth \& } \\
\text { Technology- } \\
\text { based } \\
\text { surveillance } \\
\text { tools }\end{array}$ & $\begin{array}{l}\text { Sierra - } \\
\text { Leone }\end{array}$ & $\begin{array}{l}\text { Use of self-owned } \\
\text { smartphones in community } \\
\text { mobilization. }\end{array}$ & $\begin{array}{l}\text { Quick implementation } \\
\text { of survey to obtain } \\
\text { essential and } \\
\text { geographic rural } \\
\text { information. Also led } \\
\text { to creation of updated } \\
\text { maps, all done at } \\
\text { moderate cost. }\end{array}$ \\
\hline Otu (2016) & $\begin{array}{l}\text { Mhealth \& } \\
\text { Technology- } \\
\text { based } \\
\text { surveillance } \\
\text { tools }\end{array}$ & Nigeria & $\begin{array}{l}\text { Dissemination of Ebola info } \\
\text { via tablet computers. }\end{array}$ & $\begin{array}{l}\text { Improvement of } \\
\text { knowledge of Ebola; } \\
\text { Reinforcement of } \\
\text { positive attitudes of } \\
\text { avoiding contact with } \\
\text { Ebola patients, eating } \\
\text { bush meat, and risky } \\
\text { burial practices. }\end{array}$ \\
\hline $\begin{array}{l}\text { Okware } \\
\text { (2015) }\end{array}$ & $\begin{array}{l}\text { Joint } \\
\text { community } \\
\text { mobilization } \\
\text { and palliative } \\
\text { care }\end{array}$ & Uganda & $\begin{array}{l}\text { Social mobilization; } \\
\text { voluntary quarantine; contact } \\
\text { tracing; early detection; case } \\
\text { finding and isolation }\end{array}$ & $\begin{array}{l}\text { Palliative care } \\
\text { increased odds of } \\
\text { survival; early case } \\
\text { detection and } \\
\text { treatment helped to } \\
\text { reduce EVD spread. }\end{array}$ \\
\hline $\begin{array}{l}\text { Meyer } \\
\text { Capps } \\
(2017)\end{array}$ & CLTS & Liberia & $\begin{array}{l}\text { Community education; hand } \\
\text { washing; defecation } \\
\text { infrastructure; safe disposal } \\
\text { of excreta }\end{array}$ & $\begin{array}{l}\text { CLTS reduced risk of } \\
\text { EVD, yet further } \\
\text { studies required to } \\
\text { determine if CLTS was } \\
\text { the only difference } \\
\text { between communities. }\end{array}$ \\
\hline $\begin{array}{l}\text { Abramowitz } \\
(2017)\end{array}$ & $\begin{array}{l}\text { Health } \\
\text { Communication } \\
\text { (Non-video) }\end{array}$ & Liberia & $\begin{array}{l}\text { Billboards; radio; brochures; } \\
\text { posters; }\end{array}$ & $\begin{array}{l}\text { Post-intervention, there } \\
\text { were rapid positive } \\
\text { changes in beliefs } \\
\text { about EVD, yet this } \\
\text { lagged behind } \\
\text { practices, and many } \\
\text { people still supported } \\
\text { conspiracy theories }\end{array}$ \\
\hline $\begin{array}{l}\text { Roess } \\
(2017)\end{array}$ & $\begin{array}{l}\text { Video-Centered } \\
\text { Health } \\
\text { communication }\end{array}$ & Congo & $\begin{array}{l}\text { Community members watch } \\
\text { film (movie) about Ebola }\end{array}$ & $\begin{array}{l}\text { Statistically significant } \\
\text { positive changes in } \\
\text { EVD recognition, } \\
\text { transmission, and } \\
\text { mitigation. EVD } \\
\text { knowledge gained } \\
\text { through intervention } \\
\text { was retained after one } \\
\text { year. }\end{array}$ \\
\hline $\begin{array}{l}\text { Turay } \\
(2017)\end{array}$ & $\begin{array}{l}\text { Interpersonal } \\
\text { communication }\end{array}$ & $\begin{array}{l}\text { Sierra } \\
\text { Leone }\end{array}$ & $\begin{array}{l}\text { One on one Ebola education } \\
\text { with community members }\end{array}$ & $\begin{array}{l}\text { Improved relationship } \\
\text { with external health } \\
\text { care workers; }\end{array}$ \\
\hline
\end{tabular}


increased EVD case reporting

\begin{tabular}{|c|c|c|c|c|}
\hline $\begin{array}{l}\text { Fallah } \\
\text { (2017) }\end{array}$ & $\begin{array}{l}\text { Joint field } \\
\text { blood draw and } \\
\text { point of care } \\
\text { diagnostics }\end{array}$ & Liberia & $\begin{array}{l}\text { Home-based care; point of } \\
\text { contact diagnostics }\end{array}$ & $\begin{array}{l}\text { Improved community } \\
\text { involvement; sped up } \\
\text { diagnosis and led to } \\
\text { rapid EVD case } \\
\text { isolation }\end{array}$ \\
\hline
\end{tabular}

\begin{tabular}{|c|c|c|c|c|}
\hline $\begin{array}{l}\text { Nyenswah } \\
\text { (2015) }\end{array}$ & $\begin{array}{l}\text { Community } \\
\text { Quarantine }\end{array}$ & Liberia & $\begin{array}{l}\text { Engagement of community } \\
\text { leaders; provision of basic } \\
\text { logistics during quarantine }\end{array}$ & $\begin{array}{l}\text { Led to zero reported } \\
\text { EVD cases }\end{array}$ \\
\hline
\end{tabular}

\begin{tabular}{|c|c|c|c|c|}
\hline $\begin{array}{l}\text { Pellechia } \\
\text { (2015) }\end{array}$ & $\begin{array}{l}\text { Community } \\
\text { Quarantine }\end{array}$ & Liberia & $\begin{array}{l}\text { State-imposed quarantine; } \\
\text { forced cremation }\end{array}$ & $\begin{array}{l}\text { Increased } \\
\text { condemnation, } \\
\text { stigmatization, and } \\
\text { socio-economic } \\
\text { distress }\end{array}$ \\
\hline
\end{tabular}

\begin{tabular}{|c|c|c|c|c|}
\hline $\begin{array}{l}\text { McMahon } \\
\text { (2017) }\end{array}$ & $\begin{array}{l}\text { Integration of } \\
\text { community } \\
\text { health workers, } \\
\text { volunteers and } \\
\text { formal health } \\
\text { workers }\end{array}$ & $\begin{array}{l}\text { Sierra } \\
\text { Leone }\end{array}$ & $\begin{array}{l}\text { Hiring of community } \\
\text { members as volunteers; } \\
\text { engagement of community } \\
\text { leaders; creation of health } \\
\text { management committee }\end{array}$ & $\begin{array}{l}\text { Improved trust and } \\
\text { support for EVD } \\
\text { prevention and } \\
\text { treatment; Formal } \\
\text { health workers better } \\
\text { understood and } \\
\text { addressed community } \\
\text { challenges. }\end{array}$ \\
\hline
\end{tabular}

\begin{tabular}{|c|c|c|c|c|}
\hline $\begin{array}{l}\text { Siekmans } \\
(2017)\end{array}$ & $\begin{array}{l}\text { Integration of } \\
\text { CHWs, } \\
\text { volunteers and } \\
\text { formal health } \\
\text { workers }\end{array}$ & Liberia & $\begin{array}{l}\text { Training and supervision of } \\
\mathrm{CHW}\end{array}$ & $\begin{array}{l}\text { Community members } \\
\text { saw CHWs as trusted } \\
\text { sources of EVD } \\
\text { preventive information }\end{array}$ \\
\hline
\end{tabular}

$\begin{array}{llll}\text { Miller } & \text { Integration of } & \text { Guinea, } & \text { Engagement of community } \\ \text { (2018) } & \begin{array}{l}\text { CHWs, } \\ \text { volunteers and } \\ \text { formal health } \\ \text { workers }\end{array} & \begin{array}{l}\text { Liberia, } \\ \text { Sierra }\end{array} & \begin{array}{l}\text { health workers; and other } \\ \text { community actors such as }\end{array} \\ & \begin{array}{l}\text { traditional birth attendants; } \\ \text { traditional healers; and } \\ \text { community leaders }\end{array}\end{array}$

$\begin{array}{llll}\text { Martin } & \text { Survivor Re- } & \text { Guinea } & \begin{array}{l}\text { Survivor testimony of } \\ \text { (2016) }\end{array} \\ \begin{array}{ll}\text { Integration } \\ \text { Program }\end{array} & & \text { obtained; encouraging } \\ \text { community members to seek } & \text { care. }\end{array}$

Community actors and $\mathrm{CHWs}$ helped to improve EVD response activities in spite of insufficient support, and some initial community resistance
Significant improvement in community compliance with EVD response such as contact tracing, and consequent increase in case detection.

$\begin{array}{lll}\text { Reaves } & \text { Survivor Re- } & \text { Liberia } \\ (2014) & \text { Integration } & \\ & \text { Program }\end{array}$

Community education about survivor's Ebola-free status; community celebration event; survivor given medical certificate and encouraged to share their experience in ETU; broadcasting of event via radio; in-kind donation to survivor from Firestone.

Page 18/21
Helped to improve community acceptance of EVD response, and the consequent trust reduced EVD spread 
${ }^{1} \mathrm{ETU}=$ Ebola Treatment Unit; EVD = Ebola Virus Disease; $\mathrm{CHW}=$ Community Health Workers; $\mathrm{CLTS}=$ Community-led total sanitation; $\mathrm{CEM}=$ Community education and mobilization; CCCs = Community Care Centers; CBS = Community-based surveillance

Table 3: Factors that impacted community engagement 


\section{Studies}

Jiang (2016), Nyakarahuka (2019),

Claude (2019), Vinck(2019)

Nyakarahuka (2017), Pellechia

(2015), Thiam (2015)

Caleo (2018), Gray (2018)

Gray (2018)

Caleo (2018), Sharma (2014),

Abramowitz (2015), Carrion Martin (2016)

Sharma (2014), Abramowitz (2015)

Gray (2018), Alonge (2019),

Abramowitz (2015)

Pellechia (2015)

Caleo (2018), de Vries (2016)

Sierra Leone; Uganda

Sierra Leone, Uganda

Uganda; Liberia; Guinea

Sierra Leone (both)

Sierra Leone

Sierra Leone;

Liberia (both);

Guinea

Liberia (both)

Sierra Leone; Liberia

Liberia

Uganda

Sierra Leone;

DR Congo

DR Congo

Kasereka (2019)

Kasereka (2019)

DR Congo de Vries (2016)

\section{Factors}

Risk Perception

Fear and stigma experienced by the affected and their family (or their absence thereof)

Survival rates of affected and their reintegration

Proximity to treatment facility

Transparency and communication (or lack thereof with ETU facility

Engaging or excluding families in burial process

Buy-in of community leaders

Top-down or bottom-up approaches from government

Respect for, or lack of sensitivity to local culture

Mismatch between public health information from media, and the community experience.

Enactment of bye-laws by community leaders

Satisfaction or dissatisfaction with EVD response

Denial or acceptance of biomedical discourse

Thiam (2015)

Guinea

Resources and logistics availability

Vinck (2019), Pellechia (2015)

DR Congo;

Trust between community and government Liberia

Uganda

Donor-community partnerships

Stone(2016), Carter (201)
(2016), Reaves (2014)

Alonge (2019), Hagan (2015)

Sierra Leone

Community resilience

${ }^{2}$ DR Congo = Democratic Republic of Congo; ETU = Ebola Treatment Unit 


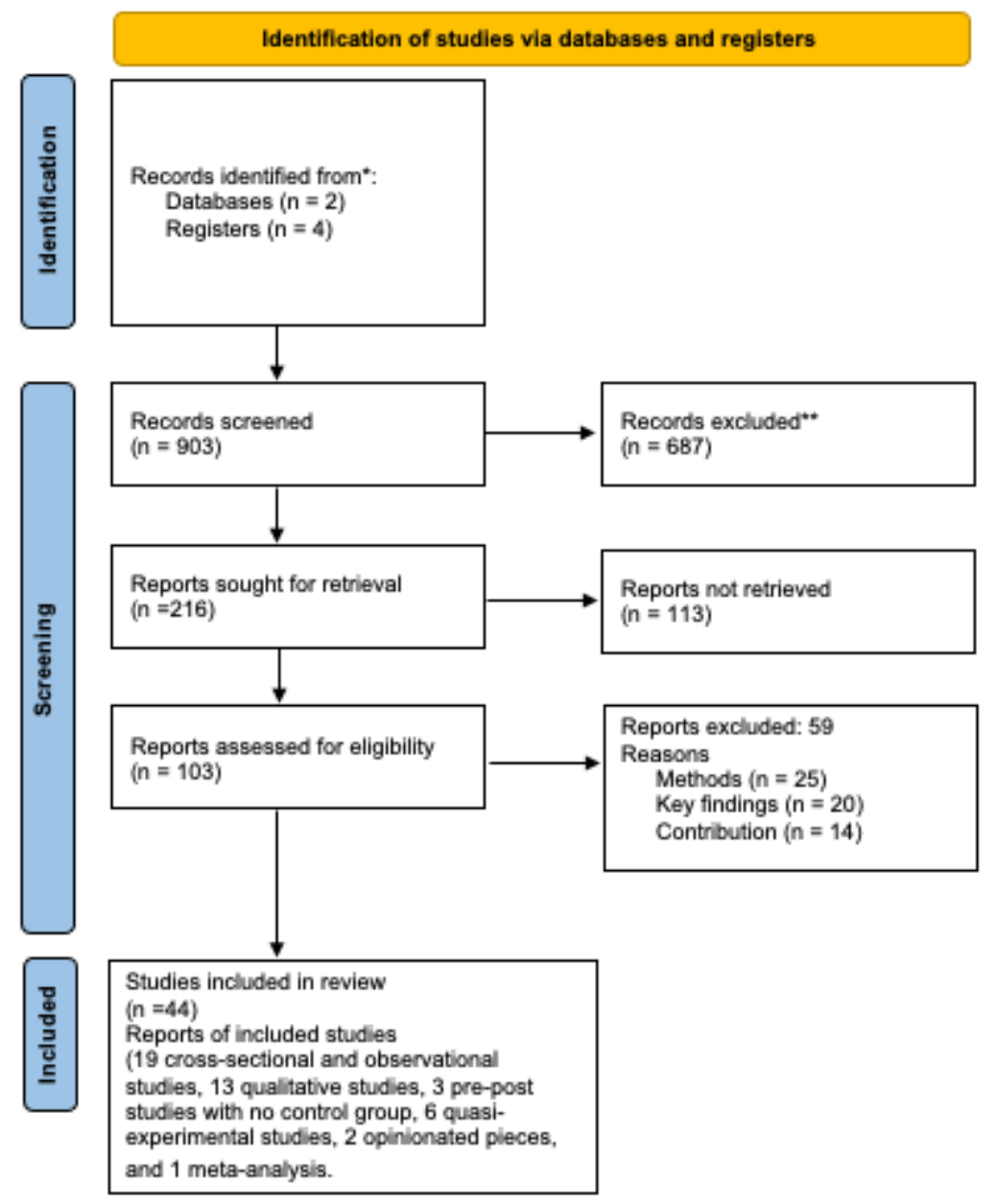

Figure 1

PRISMA FLOWCHART

\section{Supplementary Files}

This is a list of supplementary files associated with this preprint. Click to download.

- PRISMA2020checklist1.docx

- SupplementaryTables.docx 